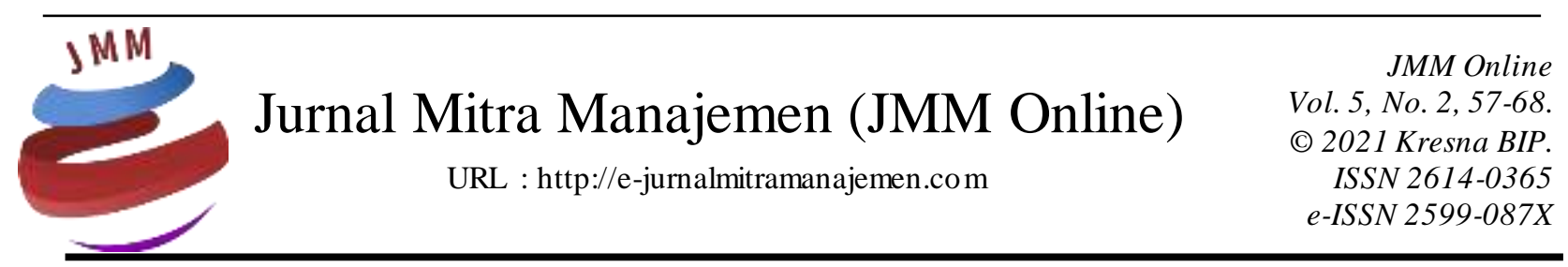

\title{
PENGARUH VALUE CHAIN TERHADAP KEPUASAN KONSUMEN DENGAN MENGGUNAKAN MEDIASI KEUNGGULAN BERSAING PADA APLIKASI GOJEK
}

\author{
Auriza Fashshalna Munawar 1), Sri Widiyanesti 2) \\ Universitas Telkom
}

INFORMASI ARTIKEL

Dikirim : 15 Februari 2021

Revisi pertama : 17 Februari 2021

Diterima : 22 Februari 2021

Tersedia online : 18 Maret 2021

Kata Kunci: Keunggulan Bersaing, Value Chain, Kepuasan Konsumen, Value Added

Email : auriza.af@gmail.com ${ }^{1)}$, widiyanesti.sri@gmail.com ${ }^{2)}$

\section{ABSTRAK}

Indonesia sedang mengalami transformasi pada bidang transportasi akibat perkembangan teknologi yang semakin pesat. Dapat dilihat dari munculnya model transpotasi online pada kota besar di Indonesia, seperti Gojek dan Grab yang berbasis aplikasi baik dalam pemesanan maupun pembayarannya. Terdapat beberapa pilihan dalampersaingan, persaingan secara harga atau persaingan secara value added. Ketika perusahaan sedang menghadapi persaingan yang kompetitif, ada beberapa hal yang harus dilakukan yaitu membuat suatu strategi untuk membuat nilai tambah atau disebut keunggulan bersaing. Salah satu membangun keunggulan bersaing dengan mengadopsi prinsip-prinsip value chain.

Penelitian ini merupakan penelitian kuantitatif dengan analisis data kausal. Pengumpulan data yang dilakukan dengan penyebaran kuisioner. Pengambilan sample pada penelitian menggunakan teknik random sampling. Berdasarkan, perhitungan jumlah sample yang digunakan dalampenelitian ini berjumlah 400 responden yang merupakan konsumen gojek yang pernah menggunakan aplikasi gojek. Pengolahan data dilakukan dengan SEM-PLS dan menggunakan sofware Smart PLS versi 3.0

Hasil penelitian menunjukan value chain memiliki pengaruh positifterhadap keunggulan bersaing, dan juga keunggulan bersaing memiliki pengaruh positif terhadap kepuasan konsumen. Hasil penelitian juga menunjukan bahwa value chain memiliki pengaruh positif terhadap kepuasan konsumen dan juga pada penelitian ini keunggulan bersaing sudah menjadi variable intervening yang baik dalam memediasi hubungan value chain dengan kepuasan konsumen.

Hal yang harus dilakukan pada pihak gojek untuk menciptakan keunggulan bersaing yang membantu meningkatkan kepuasan konsumen dengan memperbaiki pengelolaan pada value chain dan mempertahankan aktivitas yang sudah baik yang telah dilakukan oleh gojek. 


\section{PENDAHULUAN \\ Latar Belakang}

Seiring pesatnya kemajuan pada era globalisasi, penggunaan teknologi tidak lagi menjadi sebuah hal yang langka. Perkembangan teknologi semakin pesat telah memberi banyak manfaat bagi kemajuan hidup manusia (Isna, 2019). Begitu pula dengan perkembangan computer yang cukup pesat, mampu menggeser kemampuan peran manusia dalam berbagai bidang ilmu dan aktivitas manusia. Majunya bidang teknologi informasi dan komunikasi yang dicapai saat ini dirasakan memberikan banyak kemudahan bagi kehidupan umat manusia (Isna, 2019). Kemudahan serta kenyaman pada aspek teknologi informasi bisa dirasakan dari berbagai aspek salah satunya seperti dalam bidang Pendidikan, Komunikasi, Transportasi dan masih banyak lagi. Dengan berkembangnya teknologi informasi pada bidang transportasi menjadikan mobilitas masyarakat menjadi sangat terbantu. Hal ini yang akhirnya membuka peluang bisnis baru seperti aplikasi pada bidang layanan transportasi online (Isna, 2019)

Gojek memiliki kinerja yang baik dari mulai layanan GoRide hingga GoFood pada tahun 2019 mengalami kenaikan pendapatan sebesar dua kali lipat dalam setahun. Pengguna aktif aplikai gojek (meningkat 1,5 kali lipat dalam setahun. "Gojek mencetak dua kali lipat pertumbuhan pendapatan dalam satu tahun terakhir" (Merdeka, 2019). Jumlah pesanan yang terselesaikan (complete orders) pun meningkat dua kali lipat per tahun (Year on Year) hal ini dikarenakan meningkatnya transaksi di platform gojek (Merdeka, 2019)."

Value chain merupakan langkah pertama untuk menentukan posisi perusahaan dalam industri. Value chain ini dijadikan perusahaan untuk memilah-milih ke dalam berbagai aktivitas yang berlainan tetapi saling terkait. Value chain activity dapat dijadikan sumber keunggulan bersaing dan untuk memahami perilaku biaya serta sumber diferensiasi yang ada disuatu perusahaan. (Andi et al., 2015) Competitive advantage berperan untuk menghasilkan keuntungan yang mencukupi untuk waktu jangka panjang dan bisa memperoleh peluang pangsa pasar yang lebih besar dibandingkan dengan pesaing. Hal ini berdampak pada kepuasan konsumen yang menjadi lebih baik dan memiliki kekuatan untuk bertahan pada persaingan yang kompetitif (Adyandha, et al., 2018)

Konsep analisis value chain menekankan pada aktivitas-aktivitas yang dikerjakan untuk memberikan pelayanan atas produk atau jasa yang dihasilkan. Untuk menghadapi persaingan yang ketat diperlukan kualitas kinerja yang baik dalam mengendalikan faktor-faktor yang berpengaruh pada kesuksesan perusahaan tersebut. Selain itu, strategi yang tepat juga diperlukan untuk meningkatkan keunggulan bersaing. Analisis value chain merupakan solusi yang dapat diterapkan untuk mengatasi permasalahan tersebut. (Andi et al., 2015).

\section{Rumusan Masalah}

Berdasarkan latar belakang masalah yang telah diuraikan, maka dirumuskan pertanyaan sebagai berikut :

1. Apakah value chain memiliki pengaruh positif terhadap keunggulan bersaing pada aplikasi Gojek? 
2. Apakah keunggulan bersaing memiliki pengaruh positif terhadap kepuasan konsumen pada aplikasi gojek?

3. Apakah value chain memiliki pengaruh positif terhadap kepuasan konsumen pada pengguna aplikasi gojek?

4. Bagaiman keunggulan bersaing memediasi hubungan value chain terhadap kepuasan konsumen pada pengguna aplikasi gojek?

\section{Tujuan Penelitian}

Berdasarkan rumusan masalah diatas, maka tujuan dari penelitian ini adalah sebagai berikut :

1. Untuk mengetahui value chain memiliki pengaruh positif terhadap keunggulan bersaing pada aplikasi gojek.

2. Untuk mengetahui keunggulan bersaing memiliki pengaruh positif terhadap kepuasan konsumen pada pengguna aplikasi gojek.

3. Untuk mengetahui value chain memiliki pengaruh positif terhadap kepuasan konsumen pada aplikasi gojek.

4. Untuk mengetahui keunggulan bersaing dapat memediasi hubungan value chain dengan kepuasan konsumen pada aplikasi gojek.

\section{KAJIAN PUSTAKA}

\section{Manajemen Operasi}

Manajemen operasi adalah aktivitas-aktivitas yang menghasilkan nilai dalam bentuk barang dan jasa dengan harus mengubah input dari perusahaan menjadi output bagi konsumen (Jay Heizer dan Berry Rander, (2015). Menurut Heizer dan Render (2015) ada sepuluh keputusan strategis dalam Manajemen Operasional yaitu:

1. Desain barang dan jasa: menjelaskan hal-hal yang diperlukan pada kegiatan operasi misalkan : Untuk melakukan desain suatu produk

2. Pengelolaan kualitas: untuk memberikan kualitas yang terbaik untuk pelanggan serta untuk membuat kebijakan prosedur untuk mengidentifikasikan serta mencapai kualitas

3. Desain proses dan kapasitas: untuk menentukan seberapa baik kualitas barang. SDM dan investasi modal yang spesifik yang menentukan struktur biaya dasar perusahaan.

4. Pemilihan lokasi: untuk menentukan dimana lokasi akan beroperasi dengan pendekatan pelanggan serat pemasik

5. Perancangan tata letak: untuk menentukan tata letak fasilitas kerja yang dapat menunjan proses kerja.

6. Sumber daya manusia dan rancangan pekerjaan: untuk menentukan cara untuk merekrut, memotivasi serta empertahankan pekerja sesuai dengan kemampuan dan juga kebutuhan perusahaan

7. Manajemen rantai pasokan: untuk menentukan pengnintegrasian rantai pasokan ke dalam strategi perusahaan

8. Persediaan: untuk menentukan pemesanan dan persediaan dengan mempertimbangkan kapabilitas pemasok serta jadwal produksi. 
9. Penjadwalan: untuk menerapkan jadwal waktu secara efektif dan efisien baik karyawan maupun fasilitas, untuk memenuhi permintaan pelanggan.

10. Pemeliharaan: untuk menentukan siapa yang harus bertanggung jawab pada pemeliharaan kualitas agar tetap terjaga.

\section{Supply Chain Management}

Supply Chain Management adalah kegiatan untuk memperoleh barang mentah menjadi barang setengah jadi dan menjadi barang jadi yang kemudian produk akan didistribusika kepada konsumen (Haizer \& Rander, 2015).

\section{Gambar 1. Simplikasi model Supply Chain Management} dan 3 macam aliran yang di Kelola

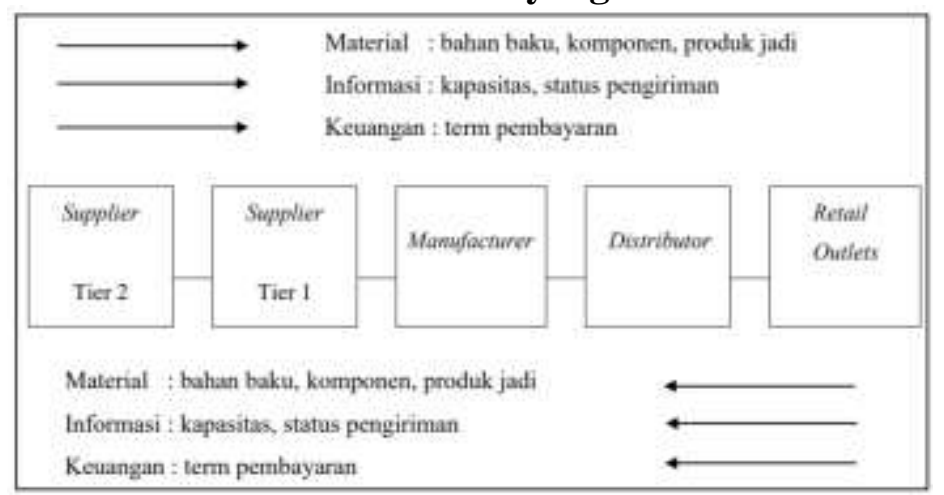

Sumber : Haizer dan Rander (2015)

\section{Value Chain}

Value chain merupakan proses bisnis sebagai rantai kegiatan untuk mengubah input menjadi output yang diaman dapat memberikan nilai kepada kosumen yang akhirnya dapat menciptakan customer value sehingga dapat menciptakan customer satisfaction (Pearce \& Robinson, 2017).

Tujuan value chain untuk perusahaan mengidentifikasi keunggulan bersaing maupun kelemahan pesaing dari beberapa sisi yang dimana akan sampai pada aktivitas layanan konsumen (Pearce \& Robinson, 2017).

\section{Keunggulan Bersaing}

Menurut Kotler (2016: 269) mendefinisikan competitive advantage (keunggulan kompetitif) adalah keunggulan yang diciptakan untuk melebihi pesaing dengan menawarkan nilai atau manfaat yang lebih besar kepada konsumen daripada tawaran pesaing. Untuk memenangkan pasar saat ini, perusahaan tidak hanya piawai dalam mengelola produk, tetapi juga dalam mengelola hubungan pelanggan untuk menciptakan competitive advantage agar mampu menghadapi persaingan yang ada.

\section{Kepuasan Konsumen}

Definisi kepuasan pelanggan menurut Kotler (2016:150) ialah "Perasaan senang atau kecewa yang muncul setelah membandingkan kinerja (hasil) produk yang dipikirkan terhadap kinerja (atau hasil) yang diharapkan"

Definisi kepuasan pelanggan menurut (Keller, 2016) ialah: "Kepuasan adalah tanggapan pelanggan atas terpenuhinya kebutuhannya. Hal itu berarti penilaian bahwa 
suatu bentuk keistimewaan dari suatu barang atau jasa ataupun barang/jasa itu sendiri, memberikan tingkat kenyamanan yang terkait dengan pemenuhan suatu kebutuhan, termasuk pemenuhan kebutuhan di bawah harapan atau pemenuhan kebutuhan harapan pelanggan."

\section{Kerangka Pemikiran}

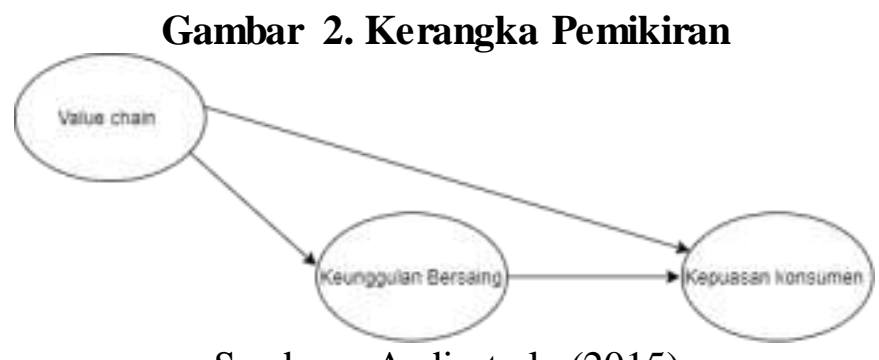

Sumber : Andi et al., (2015)

\section{Hipotesis Penelitian}

$\mathrm{H} 1$ : value chain memiliki pengaruh positif terhadap keunggulan bersaing.

$\mathrm{H} 2$ : Keunggulan bersaing memiliki pengaruh positif terhadap kepuasan konsumen.

$\mathrm{H} 3$ : value chain memiliki pengaruh positif terhadap kepuasan konsumen.

H4 : Keunggulan bersaing memediasi hubungan value chain terhadap kepuasan konsumen.

\section{METODE PENELITIAN \\ Jenis Penelitian}

Metode yang digunakan pada penelitian ini adalah metode kuantitatif dengan tujuan penelitian yaitu jenis deskriptif.

\section{Objek dan Waktu Penelitian}

Ruang lingkup penelitian ini pada penggalian korelasi antara value chain terhadap kepuasan konsumen dengan meggunakan mediasi keunggulan bersaing. Penelitian ini dibatasi dengan informasi mengenai value chain yang dimana aktivitas yang dilakukan gojek langsung kepada customer yang memusatkan kepada kepuasan konsumen. Untuk kuisioner yang akan disebarkan kepada responden adalah pertanyaan umum mengenai value chain yang diperkirakan konsumen mengatahui mengenai informasi yang akan ditanyakan. Untuk sub variable yang berhubungan dengan internal perusahaan tidak akan masuk kedalam daftar kuisioner. Adapun waktu untuk pengumpulan data yang di perlukan adalah pada bulan Desember dan Januari. Untuk data pengguna gojek yang dipakai adalah periode September 2020.

\section{Populasi}

Menurut Indrawati (2015) Populasi adalah fenomena orang, fenomena kejadian dan fenomena benda yang akan di teliti oleh peneliti. Populasi pada penelitian ini adalah konsumen Gojek yang tersebar di seluruh Indonesia. 


\section{Sample}

Menurut Indrawati (2015), populasi yang terpilih yang dimana sudah sesuai dengan kriteria yang dimana nantinya akan terlibat pada penelitian. Pada penelitian ini sample yang digunakan adalah non-probability sampling.

$$
n=\frac{Z^{2} \text { c.t.pq }}{E^{2}}
$$

Keterangan :

$\mathrm{N} \quad=$ Jumlah sampel

$Z^{2}$ c. $t$. = Tingkat kepercayaan yang dibutuhkan

$p \quad=$ Proporsi estimasi keberhasilan

$Q \quad=1-p$, atau proposi estimasi kegagalan

$E^{2} \quad=$ Maksimal allowance error

Penelitian ini menggunakan level of confidence sebesar $95 \%$ sehingga diperoleh nilai $\mathrm{Z}$ adalah 1,96 dengan tingkat kesalahan sebesar 5\% dan probabilitas untuk kuesioner benar atau salah masing-masing sebesar 0,5. Maka jumlah sampel yang didapat adalah :

$$
\begin{aligned}
& n=\frac{(1,96)^{2}(0,5)(0,5)}{(0,05)^{2}} \\
& n=384,16
\end{aligned}
$$

Berdasarkan rumus Bernoulli, jumlah sampel pada penelitian ini adalah 384,16 yang dibulatkan menjadi 385 responden.

\section{Teknik Analisis Data}

Penelitian ini merupakan penelitian kuantitatif dengan analisis data kausal. Pengumpula data yang di lakukan dengan penyebaran kuisioner. Pengambilan sample pada penelitian menggunakan teknik random sampling. Berdasarkan, perhitungan jumlah sample yang digunakan dalam penelitian ini berjumlah 385 responden yang merupakan konsumen gojek yang pernah menggunakan aplikasi gojek. Pengolahan data dilakukan dengan sem-PLS dan menggunakan sofware smart PLS versi 3.0

\section{HASIL PENELITIAN DAN PEMBAHASAN}

Analisis data dilakukan dengan empat tahap yaitu evaluasi model pengukuran (Outer Model), evaluasi model struktural (Inner Model), model Goodness of Fit (GoF), dan pembahasan hipotesis

\section{Evaluasi Model Pengukuran}

Evaluasi model pengukuran dalam penelitian dilakukan untuk menguji validitas dan reabilitas suatu konstruk. Evaluasi model pengukuran digunakan untuk mengukur model menggunakan pendekatan MTMM (Multi Trait Multi Method) dengan uji validitas yang terdiri dari validitas convergent dan validitas discriminant, sedangkan 
uji reabilitas dilakukan dengan dua acara yaitu Cronbach's Alpha dan Composite Reliability.

1. Uji Validitas

a. Validitas Convergent

Mengukur validitas convergent menggunakan nilai loading factor dan hasil penelitian menunjukan seluruh indikator dari masing-masing variabel memiliki nilai outer loading $>0.7$ yang artinya bahwa semua indikator dari konstruk variabel telah valid dan memiliki validitas convergent yang baik.

Evaluasi validitas convergent juga dapat dilakukan dengan melihat nilai Average Variance Extracted (AVE) $>0.5$ agar dinyatakan valid. Hasil pengujian nilai AVE pada variabel value chain memperoleh nilai 0,659, keunggulan bersaing memperoleh nila 0,752, kepuasan konsumen memperoleh nilai 0,700. Sehingga dapat disimpulkan bahwa seluruh indikator telah valid dan telah mencapai validitas yang menunjukan setiap indikatr sudah menjelakan variabelnya masing-masing.

b. Validitas Discriminant

Pengujian lain untuk validitas diskriminan dapat dilakukan dengan uji rasio korelasi Heterotrait-Monotrait Ratio (HTMT). Menunjukan bahwa nilai HTMT di bawah 0.9, maka penelitian ini dikatakan valid. Hal ini menunjukan bahwa setiap manifes pada setiap konstruk benar-benar merupakan alat ukur yang tepat untuk mengukur konstruk tersebut.

Pengujian lain untuk mengukur validitas discriminant yaitu dengan Heterotrait-Monotrait Ratio of Correlations (HTMT). Pendekatan HTMT mampu mencapai penilaian kekhususan dan sensitivitas tinggi mencapai 97\%99\%. Hasil pengujian HTMT menunjukan keseluruhan nilai $<0.85$ yang dapat dinyatakan mencapai validitas discriminant yang baik.

2. Uji Realibilitas

a. Cronbach's Alpha

Hasil uji cronbach's alpha dikatakan baik karena keseluruhan variabel mendapatkan nilai > 0.7. Variabel value chain mendapatkan nilai 0.960, keunggulan bersaing mendapatkan nilai 0.953, kepuasan konsumen mendapatkan nilai 0.893 .

b. Composite Reliability

Pengujian lain yang dapat digunakan dalam uji reliabilitas adalah composite reliability. Nilai keseluruhan indikator dari masing-masing konstruk variabel memperoleh nilai $>0.7$. Variabel value chain memperoleh nilai 0.964 , keunggulan bersaing memperoleh nilai 0.960, kepuasan konsumen memperoleh nilai 0.921 .

\section{Evaluasi Model Pengukuran (Inner Model)}

Pengujian model struktural dilakukan untuk memprediksi hubungan kausal antara variabel dan pengujian hipotesis [10]. Evaluasi model struktural dilakukan dengan melihat nilai $\mathrm{R}$ - Square $\left(\mathrm{R}^{2}\right)$ dan predictice relevance $\left(\mathrm{Q}^{2}\right)$. 


\section{R-Square $\left(\mathbf{R}^{2}\right)$}

Tabel 1. Evaluasi Model Struktural

\begin{tabular}{|l|l|l|}
\hline & R Square & Kategori \\
\hline Keunggulan Bersaing & 0,399 & Moderat (Sedang) \\
\hline Kepuasan Konsumen & 0,621 & Moderat (Sedang) \\
\hline
\end{tabular}

Sumber : Hasil Penelitian, diolah (2020)

$\mathrm{R}^{2}$ keunggulan bersaing sebesar 0,599 >0,50 tergolong sedang, hasil tersebut menjelaskan bahwa 39,9\% keunggulan bersaing dipengaruhi oleh value chain sedangkan sisanya yaitu sebesar $60,1 \%$ dipengaruhi oleh faktor lain yang tidak diamati di dalam penelitian ini. Sementara untuk nilai $\mathrm{R}^{2}$ kepuasan konsumen adalah sebesar 0,621> 0,5 tergolong moderat (sedang), hasil tersebut menjelaskan bahwa 62,1\% kepuasan konsumen dipengaruhi oleh value chain dan keunggulan bersaing, sedangkan $37,9 \%$ dipengaruhi oleh faktor lain yang tidak diamati di dalam penelitian ini.

\section{Predictive Relevance $\left(Q^{2}\right)$}

Berdasarkan hasil perhitungan didapatkan nilai Q-square sebesar 0,734 yang memperlihatkan nilai Q-square lebih dari 0 (nol), maka dalam penelitian ini model layak dikatakan memiliki nilai prediktif yang relevan.

\section{Goodness of Fit (GOF)}

Tabel 2. Overall Model Fit

\begin{tabular}{|l|l|l|}
\hline Variabel & (AVE) & R Square \\
\hline Value Chain & 0,659 & 0,299 \\
\hline Keunggulan Bersaing & 0,752 & 0,621 \\
\hline Kepuasan Konsumen & 0,700 & - \\
\hline Rata-rata & $\mathbf{0 , 7 0 4}$ & $\mathbf{0 , 4 6 0}$ \\
\hline Niali GoF (Sesuai Rumus) & $\mathbf{0 , 5 6 9}$ \\
\hline Kesimpulan & Nilai GoF besar (Model Fit) \\
\hline
\end{tabular}

Sumber : Hasil Penelitian, diolah (2020)

Diketahui bahwa kesesuaian model secara keseluruhan memperlihatkan nilai sebesar 0,569. Hal ini menujukkan bahwa model yang dibentuk dalam penelitian ini secara keseluruhan memiliki kekuatan prediksi yang kuat atau dengan kata lain bahwa miidel memenuhi kriteria goodness of fit.

\section{Pembahasan Hipotesis}

Hasil pengujian hipotesis dilakukan dengan proses bootstrapping menggunakan software SmartPLS 3.0 yang ditunjukan pada Gambar 3. 
Gambar 3. Diagram Jalur Nilai t-statistik

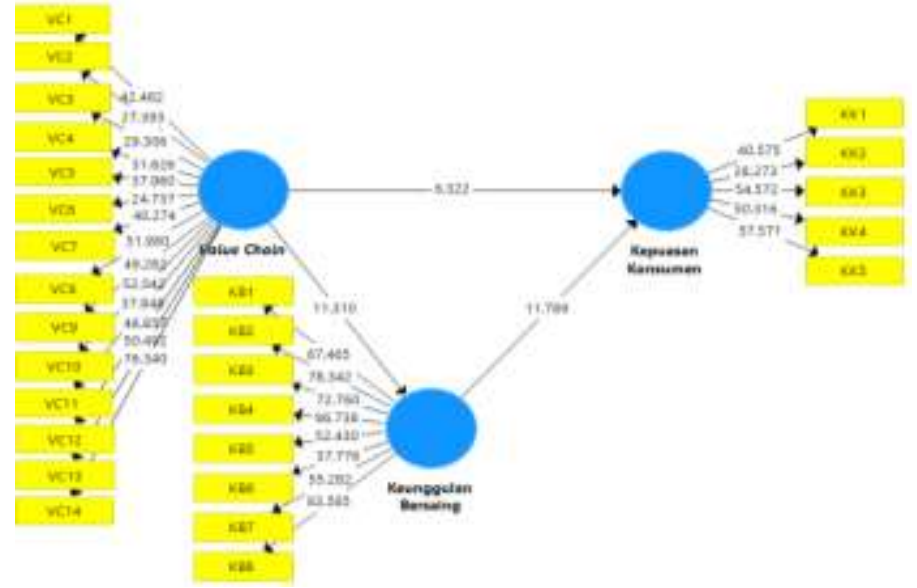

Sumber : Pengolahan Data dengan SmartPLS 3.0

Pengaruh Value Chain Terhadap Keunggulan Bersaing

Tabel 3. Hasil Uji Pengaruh Langsung dan Uji Signifikansi Value Chain Terhadap Keunggulan Bersaing

\begin{tabular}{|ll|l|l|l|l|}
\hline & & $\begin{array}{l}\text { Original } \\
\text { Sample }\end{array}$ & $\begin{array}{l}\text { T } \\
\text { Statistics }\end{array}$ & $\begin{array}{l}\text { P } \\
\text { Values }\end{array}$ & Keterangan \\
\hline $\begin{array}{l}\text { Value Chain } \\
\text { Keunggulan Bersaing }\end{array}$ & 0,546 & 11,310 & 0,000 & Signifikan \\
\hline
\end{tabular}

Sumber : Hasil Penelitian, diolah (2020)

Hasil pengujian yang ditampilkan pada pada tabel 3 menunjukkan nilai path coefficient sebesar 0,546 signifikan pada $t$-statistic 11,310 > t-tabel 1,64 dan pada $P$ value $0,000<$ tingkat signifikansi 0,05 . Dengan demikian Hipotesis yang menyatakan bahwa terdapat pengaruh positif value chain terhadap keunggulan bersaing dapat diterima, atau dengan kata lain terdapat pengaruh yang signifikan dari value chain terhadap keunggulan bersaing.

Pengaruh Keunggulan Bersaing Terhadap Kepuasan Konsumen

Tabel 4. Hasil Uji Pengaruh Langsung Dan Uji Signifikansi Keunggulan Bersaing Terhadap Kepuasan Konsumen

\begin{tabular}{|c|c|c|c|c|}
\hline & $\begin{array}{l}\text { Original } \\
\text { Sample }\end{array}$ & $\begin{array}{l}\mathbf{T} \\
\text { Statistics }\end{array}$ & $\begin{array}{l}\mathbf{P} \\
\text { Values }\end{array}$ & Keterangan \\
\hline $\begin{array}{l}\text { Keunggulan Bersaing } \\
\text { Kepuasan Konsumen }\end{array}$ & 0,559 & 11,789 & 0,000 & Signifikan \\
\hline
\end{tabular}

Sumber : Hasil Penelitian, diolah (2020)

Hasil pengujian yang ditampilkan pada pada tabel 4.23 menunjukkan nilai path coefficient sebesar 0,559 signifikan pada $t$-statistic $11,789>\mathrm{t}$-tabel 1,64 dan pada $P$ value $0,000<$ tingkat signifikansi 0,05 . Dengan demikian Hipotesis yang menyatakan bahwa terdapat pengaruh positif keunggulan bersaing terhadap kepuasan konsumen dapat diterima, atau dengan kata lain terdapat pengaruh yang signifikan dari keunggulan bersaing terhadap kepuasan konsumen. 
Pengaruh Value Chain Terhadap Kepuasan Konsumen

Tabel 5. Hasil Uji Pengaruh Langsung Dan Uji Signifikansi Value Chain Terhadap Kepuasan Konsumen

\begin{tabular}{|l|l|l|l|l|}
\hline & $\begin{array}{l}\text { Original } \\
\text { Sample }\end{array}$ & $\begin{array}{l}\text { T } \\
\text { Statistics }\end{array}$ & $\begin{array}{l}\text { P } \\
\text { Values }\end{array}$ & Keterangan \\
\hline $\begin{array}{l}\text { Value Chain } \\
\text { Konsumen }\end{array}$ & 0,329 & 6,322 & 0,000 & Signifikan \\
\hline
\end{tabular}

Sumber : Hasil Penelitian, diolah (2020)

Hasil pengujian yang ditampilkan pada pada tabel 4.24 menunjukkan nilai path coefficient sebesar 0,329 signifikan pada t-statistic 6,322>t-tabel 1,64 dan pada $P$ value $0,000<$ tingkat signifikansi 0,05 . Dengan demikian Hipotesis yang menyatakan bahwa terdapat pengaruh positif value chain terhadap kepuasan konsumen dapat diterima, atau dengan kata lain terdapat pengaruh yang signifikan dari value chain terhadap kepuasan konsumen.

\section{Pengaruh Tidak Langsung Value Chain Terhadap Kepuasan Konsumen Melalui Keunggulan Bersaing}

Tabel 6. Hasil Uji keunguulan bersaing menjadi mediasi antara value chain dengan kepuasan konsumen

\begin{tabular}{|ll|l|l|l|l|}
\hline & & $\begin{array}{l}\text { Original } \\
\text { Sample }\end{array}$ & $\begin{array}{l}\text { T } \\
\text { Statistics }\end{array}$ & $\begin{array}{l}\text { P } \\
\text { Values }\end{array}$ & Keterangan \\
\hline $\begin{array}{l}\text { Value Chain } \\
\text { Keunggulan Bersaing } \\
\text { Kepuasan Konsumen }\end{array}$ & $->$ & 0,305 & 8,179 & 0,000 & Signifikan \\
\hline
\end{tabular}

Sumber : Hasil Penelitian, diolah (2020)

Hasil pengujian yang ditampilkan pada pada tabel 4.25 menunjukkan nilai path coefficient sebesar 0,305 signifikan pada t-statistic $8,179>$ t-tabel 1,64 dan pada $P$ value $0,000<$ tingkat signifikansi 0,05 . Dengan demikian Hipotesis yang menyatakan bahwa terdapat pengaruh yang signifikan antara value chain terhadap kepuasan konsumen melalui keunggulan bersaing dapat diterima, dengan kata lain bahwa keunggulan bersaing memediasi pengaruh value chain terhadap kepuasan konsumen dengan arah yang positif.

\section{KESIMPULAN DAN SARAN}

\section{Kesimpulan}

1. Dari hasil analisis dan uji hipotesis yang telah dilakukan membuktikan bahwa terdapat pengaruh positif dan signifikan dari value chain terhadap keunggulan bersaing Aplikasi Gojek.

2. Dari hasil analisis dan uji hipotesis yang telah dilakukan membuktikan bahwa terdapat pengaruh positif signifikan dari keunggulan bersaing terhadap kepuasan konsumen Aplikasi Gojek.

3. Dari hasil analisis dan uji hipotesis yang telah dilakukan membuktikan bahwa terdapat pengaruh positif dan signifikan dari value chain terhadap kepuasan konsumen Aplikasi Gojek. 
4. Dari hasil analisis dan uji hipotesis yang telah dilakukan membuktikan bahwa terdapat pengaruh positif dan signifikan dari value chain terhadap kepuasan konsumen melalui keunggulan bersaing Aplikasi Gojek.

\section{Saran}

\section{Aspek Praktis}

1. Value chain memiliki pengaruh positif terhadap keunggulan bersaing pada aplikasi gojek. Pengelolaan value chain gojek harus dapat dilakukan agar terus menciptakan keunggulan bersaing dengan cara meningkatkan service atau pelayanan denga cara menambah jumlah armada yang ada seperti (GoRide dan GoCar) yang dimana dengan menambah jumlah armada akan memudahkan untuk melayani konsumen dibanding dengan pesaing nya.

2. Keunggulan bersaing memiliki pengaruh positif terhadap kepuasan konsumen pada aplikasi gojek. Untuk meningkatkan kepuasan konsumen dengan menawarkan harga yang lebih kompetitif dengan pesaing agar konsumen tidak berpindah ke competitor lain

3. Value chain memiliki pengaruh positif terhadap kepuasan konsumen pada aplikasi gojek. Untuk meningkatkan kepuasan konsumen gojek harus lebih tanggao dalam mengangani masalah atau keuhan konsumen yang dimana nantinya daoat menjadi bahan evaluasi untuk gojek, Dengan memberlakukan layanan konsumen selama 1x24 jam dan juga memberikan informasi dengan jelas mengenai bagaimana konsumen apabila memiliki keluhan mengenai driver atau layanan yang di berikan.

4. Value chain memiliki pengaruh positif terhadap kepuasan konsumen melalui keunggulan bersaing pada aplikasi gojek. Pengelolaan value chain yang harus gojek lakukan agar terus meningkatkan kepuasan konsumen dengan mempertahankan keterampilan masing-masing gojek dalam menetapkan harga untuk merespon konsumen melalui keunggulan bersaing. Untuk memberikan alternatif layanan yang disesuaikan dengan kebutuhan pelanggan karena menjadi instrument yang paling penting dalam mengukur value chain.

\section{Aspek Teoritis}

1. Pada penelitian selanjutnya disarakan untuk melakukan penelitian pada objek yang berbeda. Bisa melakukan penelitan terhadap kompetitor baru pada layanan transportasi online sehingga nantinya akan menghasilkan hasil penelitian yang berbeda.

2. Hasil penelitian menunjukan keunggulan bersaing menjadi variable intervening yang baik karena dapat memediasi value chain terhadap kepuasan konsumen. Oleh karena itu pada penelitian selanjutnya dapat mengeksplorasi variable intervening lainnya selain variable keunggulan bersaing yang sudah terbukti

\section{DAFTAR PUSTAKA}

Adyandha, et al. 2018. Faktor-Faktor Yang Menentukan Preferensi Masyarakat Kota Bandung Terhadap Moda Transportasi Taksi Berbasis Aplikasi Online. Prosiding Ilmu Ekonomi, Vol. 4, No, 1, 2018. 
Andi Maddeppungeng, I. S. 2015. Analisis Pengaruh Value Chain Terhadap Keunggulan Bersaing untuk Mencapai Kepuasan Konsumen. JURNAL FONDASI, Volume 4 No 1.

Heizer, Jay dan Render, Barry. 2015. Manajemen Operasi: Manajemen Keberlangsungan Rantai Pasokan Edisi 11. Jakarta: Salemba Empat.

Indrawati. 2015. Metode Penelitian Manajemen dan Bisnis Konvergensi Teknologi Komunikasidan Informasi. Bandung: Refika Aditama.

Isna, T. D. 2019. Go-Jek : Go-Food 4 Kali Lebih Besar Dari Kompetitor. Warta Ekonomi, [Online], halaman $1 . \quad$ Tersedia https://www.wartaekonomi.co.id/read223486/go-jek-go-food-4-kali-lebih- besardari-kompetitor.html

Keller, P. K. 2016. Marketing Management, 15th. Jakarta: PT. Indeks.

Kotler, Philip dan Armstrong, Gray. 2016. Prinsip-Prinsip Pemasaran Edisi 12. Jakarta: Erlangga.

Pearce, John A dan Richard B. Robinson. 2008. Manajemen Strategis Buku 1 Edisi 10. Jakarta: Salemba Empat.

Wilfridus, S. E. 2019. Jumlah Pesanan Go-Food Diklaim Meningkat 133\%. Merdeka, [Online], halaman $1 . \quad$ Tersedia:

https:/www.merdeka.com/uang/jumlah-pesanan-go-food-diklaim- meningkat133-persen.html 